\title{
Optimizing Physical Planning in the Developing Countries - A Case Study of Ondo State, Nigeria
}

\author{
A. E Olajuyigbe (Corresponding author) \& O. O Rotowa \\ Department of Urban and Regional Planning, Federal University of Technology \\ P.M.B 704, Akure, Nigeria \\ E-mail: olajuyigbe03@yahoo.com
}

Received: October 22, 2010

Accepted: May 15, 2011

doi:10.5539/jsd.v4n4p202

\begin{abstract}
A new Ministry of Physical Planning and Urban Development has just been established in Ondo State, Nigeria. The development was expected to herald efficient and sustainable physical planning. To maximize the opportunities offered by this innovative development, some conditions are desirable. This paper therefore examined the problems confronting physical planning in the State and proffer appropriate solutions to unravel them with the intention of optimizing the gains arising from this innovation. The study involved a survey of physical planning mechanisms and agencies of governments responsible for physical planning in Ondo State. It investigated the evolution of physical planning in the state. Other variables examined include: human and financial capacity available for physical planning, development control process, master planning, inventory of project vehicles and equipment among others. The problems that were identified include lack of urban development policy, ineffective development control, inadequate/absence of capacity in appropriate discipline, dearth of spatial information and data and absence of master plan to guide the development of settlements in the State. The paper therefore canvassed for immediate evolvement of urban development policy coupled with series of legislations and regulations that would facilitate development control. Other recommendations include capacity building in relevant discipline, recruitment of staff with contemporary knowledge in urban planning, acquisition of spatial information and data for planning purposes and the immediate development of master plans for major settlements in the State.
\end{abstract}

Keywords: Physical planning, Urban development policy, Development control, Capacity building, Spatial information

\section{Introduction}

Planning has been described in various ways as land use planning, town and country planning, urban and regional planning, or simply town planning. Planning is described as the systematic assessment of land and water, alternative pattern of land use and other physical, social and economic conditions in such a way to encourage land user to select options that increase productivity and meet societal needs in a sustainable manner (Onibokun, 1985). Succinctly put, it is the art and science of organizing the use of land for the greater good of the society. Land use planning could therefore be expressed as physical planning. This is because physical planning attempts to achieve an optimal spatial coordination of different human activities for the enhancement of the quality of life. Physical planning involves the reconciliation of land uses, provision of the right site for the right use, control of development, provision of facilities, services and public goods, preservation, protection and conservation of resources, preservation of heritage among others (Oduwaye, 2009). It ensures compatible land uses, guarantees orderly development and provides functional and visually pleasing environment and satisfactory services in a sustainable manner. It is the spatial expression of the desired form of social and economic development. In other word, physical planning established the 'ground rules' for sustainable development as it ensures that developments are carried out without harming the environment. Again, the process ensures that such developments are socially just. According to Oyesiku (1997), effective urban land control and management particularly in areas with rapid urban sprawl is crucial to tackling growing land use problems such as slum formation, rising costs of land, accessibility to urban land for housing, incompatible use, flooding, overcrowding and congestion among others for the purpose of achieving sustainable city development and ensure the safety and health of the people.

Sub Saharan Africa is presently witnessing an astronomically high population growth rate. Many countries in this sub-region need only 17 years to double their population (Alabi, 2010). For example, it has been inferred that major Nigerian cities exhibit a population growth rate of about 10\% (Alabi, 2010). Unfortunately, such rapid urbanization is not usually accompanied with efficient planning in the developing countries leading to unpleasant consequences of urbanization. Aribigbola (2007) contends that Nigerian cities are already showing symptoms of such rapid urbanization. These include inadequate housing and lack or inadequate basic services. Evidence of proliferation of shanties and squatter settlements largely characterized by squalid environment abound in large 
urban centers in Nigeria. Such settlements are unplanned and lack basic social infrastructures. No doubt, such physical environment endangers safety, economy, convenience and aesthetics.

In Nigeria, series of legal and policy provisions that gave credence to physical planning activities have been evolved and implemented. These include the Land use Act of 1978, Urban Development Policy of 1992, Urban and Regional Planning Act 1992 as well as the Housing and Urban Development Policy of 2002. In like manner, physical planning control measures have been introduced to improve urban land use planning and urban development (Alabi and Akinbode, 2010; Aribigbola, 2008). Irrespective of these robust laws and policies, urban centres in Nigeria are still plagued with problems arising from ineffective physical planning. Aribigbola (2008) observed that land use management is ineffective and uncoordinated in Ondo state, Nigeria. He identified the following factors as responsible for this scenario. They include non adoption and utilization of modern planning approaches; outdated and outmoded land use planning policies, laws and regulations; inadequate manpower; poor and inadequate funding as well as inadequate institutional framework for land management. The outcome of the shortcomings itemized above is that physical planning in Ondo State falls short of expectation. Aribigbola (2007) therefore calls for decentralization of physical planning in Nigeria using Local Planning Authority as its plank.

Prior 2008 in Ondo State, physical planning activities was centred under a Ministry (Ministry of Works and Transport or the Ministry of Lands and Housing). Under this arrangement, physical planning became very ineffective since it has to compete with the activities of other Departments in the Ministry for both human and financial resources. It was in realization of this challenge that the government created a new Ministry of Physical Planning and Urban Development in 2008 with a substantive commissioner. This decision was to usher in an era of efficient and sustainable physical planning process in the State. In a bid to optimize the advantages arising from this new arrangement, it becomes apposite to create an enabling environment for operation of physical planning tools in the State. This paper therefore examined the problems confronting physical planning in Ondo State and proffer appropriate solutions to unravel them with the intention of maximizing the gains arising from the creation of an autonomous Ministry of Physical Planning and Urban Development.

\section{Materials and Methods}

\subsection{The Research Locale}

Ondo State situates in the South West of Nigeria (Fig. 1). The State was created on February $3^{\text {rd }} 1976$ from the former Western State. It lies within latitudes $5^{\circ} 45^{\prime}$ and $8^{\circ} 15^{\prime}$ North and longitudes $4^{\circ} 45^{\prime}$ and $5^{\circ} 6^{\prime}$ East. The State has a population of about 3.4 million people (National Planning Commission, 2006) with an annual urban growth rate of $5.68 \%$. The State has a surface area of approximately $15317 \mathrm{~km}^{2}$, which represents $1.66 \%$ of the total surface area of Nigeria. With its 18-Local Government Area structure, the southern tip of the State rests on a 71-km coastline of the Atlantic Ocean with considerable territorial waters offshore. Therefore, the State is rich in aquatic resources.

The rate of urbanization and urban growth in the State is phenomenal because more than half of the current population is located within the urban setting. Its economy is the sixth largest in Nigeria and is dominated by crude oil and agricultural production which jointly account for $90 \%$ of its Gross State Product. In addition, the State has the largest reserve of tar sand (bitumen) and gas in the country. Other mineral resources that abound in the State include gold, iron ore and limestone. With its natural fertile soil, a variety of food and tree crops are produced in the State. The food crops include cassava, yam, maize and coco-yam, rice, melon, sweet potato, plantain, cowpeas and groundnut. Some of the notable tree crops are cocoa, oil palm, coffee, rubber

Akure, the capital city, has a population of about 387000 (National Population Commission, 2006). The city is the economic nerve centre of the State.

With these great potentials, urban centres in the State are under tremendous pressure for basic infrastructure and services in order to cope with the growth that is underway. However, since the creation of Ondo State in 1976, urban development effort has remained disjointed and uncoordinated resulting in rapid decaying of infrastructure and epileptic services. In general, a notable feature of many urban centres in the State is their disorderly nature. This is so because these urban centres have grown on their own without any form of physical plans, standards and regulations to guide them at their formation.

\subsection{The Database}

The study involved an extensive and systematic survey of physical planning mechanisms and agencies of governments responsible for physical planning in Ondo State. It therefore entailed retrieval of historical information on the evolution of physical planning in the state, review of the available human capacity, assessment of financial resources appropriated for physical planning over the years, inventory of project vehicles and equipment, records on master plans, review of development control process among others. In addition, stakeholders in the built environment were interviewed while additional data were sourced from published materials, journal articles, internet among others. Data collection commenced in October 2009 and ended in July, 2010. 


\section{Results and Discussion}

\subsection{Evolution of Physical Planning in Ondo State}

Nigeria as whole had a long history of Ordinances guiding physical development, but the most relevant one to Ondo State is the 1946 Ordinance which was later reviewed in the then Western Region and adopted as Nigeria Town and Country Planning Law Cap 123 of 1958. The law was to apply to all parts of the Region of which Ondo State was an integral part. Consequently, Town Planning Authorities were established in a number of towns in the present Ondo State. In 1973, the Town Planning Authorities were changed to the status of Area Town Planning Authorities so as to have effective administrative control of their locations. In March 1979, these Area Town Planning Authorities were merged and 17 Area Town Planning Offices were created.

As from this time of merger, Urban and Regional Planning used to be a department in the Ministry of Lands and Housing. Consequently, the administration and management of Physical Planning falls within the realms of the Ondo State Civil Service. Physical Planning was managed and administered by the Ministry which has the Commissioner as the political head and the Permanent Secretary as the head of the administration. Under the Ministry, Physical Planning administration was centralized in the State and was subjected to the Civil Service framework and bureaucratic operational guide. The order flows from the Governor down the organization structure to the Area Officer.

This present administration created a separate Ministry for Physical Planning and Urban Development in March 2008. The new Ministry inherited the existing planning laws, subdivision regulations, planning standards and other ministerial circulars to administer physical planning in the State. The central planning administration has some far reaching effects on Town Planning Administration in the State. These include: excessive centralization of power at the Headquarters, slow decision making process due to bureaucracy, poor funding of offices, inadequate manpower to function in the Area Offices, and lack of participation of the local people in the physical planning activities that affect their localities.

In 1999, Ondo State passed into law the Ondo State Planning Board and Local Planning Authorities Edict 2 of 1999. The Edict aimed at correcting the problems created by the excessive centralization of planning administration and also the shortcomings of the 1946 Ordinance under which physical planning was being operated in Ondo State. As good as the Edict is, it was never implemented.

\subsection{Urban Development Policy}

The place of policy in any meaningful intervention in all development sectors cannot be overemphasized. Without an articulate policy, it becomes difficult to effectively characterize, manage and improve an urban system. Such policy also provides a plank for evolving laws and regulations guiding the use of land. Paradoxically, since its creation in 1976, Ondo State is yet to evolve a policy on urban management. However, Ondo State government enacted the State's version of the 1992 National Urban and Regional Planning Law in 1999. Several years after the enactment, it is yet to be implemented. In order to adequately decentralize planning functions, the 1992 National Urban and Regional Planning law made provisions for three tiers of governance. These are the National Urban and Regional Planning Commission at the federal level; the State Urban and Regional Planning Board at the state level and a Local Planning Authority (LPA) in each of the local Government Areas and the Councils of the Federation. The implication of non-implementation of this planning administration is that physical planning has been subjected to administrative bureaucracy that is making it rather ineffective in the state. Major planning approval decisions are unusually delayed since they are taken at the headquarters. In addition, its impacts are far from being felt at the grassroots since physical planning activities are concentrated at the state capital and other few large urban centres especially the LGAs headquarters. Such restriction has not only affected grassroots participation in physical planning decision making process but also the revenue that is expected to be generated through physical planning activities in the State. For effective physical planning process, a system that concentrates planning administration at the headquarters cannot cope with the expectations of this new dispensation.

\subsection{Human Resources}

The Ministry exhibits a clear evidence of weak human capacity in terms of quantity and quality. In the country, the Town Planners Registration Council of Nigeria is the body established by Law to license town planners to practice the profession of urban and regional planning. Town Planners that are registered by this body usually have academic qualifications such as Full Town Planning Diploma, Bachelors Degrees and Masters Degrees. The Ministry currently possesses 20 of such professionals. This represents about $31 \%$ of the expected number of professionals that would be required for effective operation of physical planning in the State (Table 1). The technical staff who are to assist the professional officers especially in development control and other monitoring activities are also in short supply as the Ministry could only meet $33.1 \%$ of the capacity need of this category of staff in the State (Table 1). It is however appreciated that a substantial proportion of this group of personnel are trainable as they possess academic qualifications that are above GCE Ordinary Level. The administrative staff who are expected to back-up the activities of both the professional and technical staff especially in the area of record keeping, revenue collection are fairly in good supply as only about $23 \%$ capacity gap was recorded (Table 1 ). The 
implication of the above scenario is that the existing capacity cannot cope with the expectations of the newly established Ministry in the State.

Some special skills especially in the area of quality information collection and processing are required for effective physical planning operation. These include Remote Sensing (RS), Geographical Information Systems (GIS), Disaster Management (DM) and Coastal Zone Management and Planning. It is astonishing to observe that only 1 one of the personnel has fair knowledge of both RS and GIS (Table 2). In the modern day, rapid information are required especially in the area of development control and disaster management to facilitate swift response to planning issues. In addition, some of these information need to be obtained remotely especially in the inaccessible coastal areas of the State. Currently none of the personnel has the knowledge of Disaster Management and Coastal Zone Management and Planning. With a 71-km coastline representing the longest paraded by any State in Nigeria, it is unimaginable that the physical planning system does not have any skill in coastal management. Again the State is susceptible to disaster as it has huge deposit of gas, crude oil, bitumen and several hectares of reserved forests. It is another paradox that the physical planning system in the state is not adequately equipped in terms of skills to meet the challenges posed by these risk factors.

A formidable means of beefing up the capacity of government personnel is usually through training and re-training. It is an irony that in the past five years only 35 of the personnel representing $14.1 \%$ of the total number of staff in the Ministry benefitted from such training (Table 3). All the training are short time courses ranging from four weeks to three months. Again, all the courses were done within the country. Investigations revealed that irrespective of the abundant number of institutes offering physical planning related courses in Nigeria, the Ministry does not have any collaborative arrangement with any of them for capacity training. Such institutes include the Regional Centre for Aerial Survey (RECTAS), Ile-Ife, Centre for Research in Space Studies (CESRA), The Federal University of Technology, Akure, the newly established Department of Geographical Information Technology (GIT), The Federal University of Technology, Akure and National Space Research and Development Agency of Nigeria (NARSDA).

\subsection{Planning Data}

Spatial or geo-information in the form of maps, plans, aerial photographs, satellite imageries among others have always formed the physical base on which settlements development planning is undertaken. It has earlier been emphasized that the ability of cities to manage urban growth is increasingly dependent on timely access to spatial information and the competence of turning these data into information to support decision-making. It is absurd to observe that the Ministry cannot boast of satellite imageries while the existing maps and aerial photographs are obsolete. The most recent set of aerial photographs of the state capital was taken in 1979. Again, only one staff of the Ministry is equipped with these modern techniques of information collection and analysis (Table 2).

No realistic and sustainable physical planning and development management can be done without adequate spatial information base. Economically, socially and ecologically/environmentally sustainable development planning of towns and cities is difficult and potentially ineffective in the absence of reasonably adequate information regarding the available land on which settlement is to be sited and its characteristics - its relative location, size, quality, main physical features, or terrain, its natural resources and current uses among others. Without adequate information on these, it is difficult to plan, subdivide, develop and provide appropriately for shelter, infrastructure, utilities and services or to protect and manage the environment. It is also difficult without these information to assign appropriate titles and tenure to land and property parcels, or to effectively assess and collect property revenue thereof (Okpala 2001). Consequently, effective physical planning depends on the strength and authenticity of the spatial information on which it must invariably be based.

\subsection{Master Planning}

Master plan constitutes a fulcrum for effective development of cities. Again, development control cannot be effective when not built on an efficient and workable master plan. Irrespective of its importance, it is disheartening to observe that only five (5) settlements (Akure, Ondo, Ore, Ikare and Owo) in the state have master plans. This figure becomes significant when one realises that the state has 16 LGAs. Each of these LGAs has fairly big headquarters that are also growing rapidly in an uncoordinated manner. Again, all the master plans are obsolete and outdated. It took between 11 and 21 years to have these master plans reviewed for Akure, Ondo and Ore, while to date, those of Owo and Ikare are yet to be reviewed (Table 4).

\subsection{Funding}

Enough funds have not been appropriated for physical planning and urban development over the years in the State. A cursory examination of the capital budget on physical planning and urban development in the State between 2007 and 2010 confirms this conclusion (Table 5). It is unimaginable that only about USD9 million was appropriated for physical planning and urban development during this period. A State having a significant proportion of its settlements as urban cannot justify such ominous appropriation. Again, an unimpressive proportion of these budget estimates was actually released by the government. Specifically, only $60 \%, 50 \%$ and $59.1 \%$ of the amount appropriated for physical planning and urban development were released in 2007, 2008 and 2009 respectively. The implication of this is that funds were never sufficient for preparation of master plans, 
development control, capacity building and other requirements of an effective physical planning system. One however observed with relish, the significant improvement in the budget estimate for 2010 during which USD8.72 million was appropriated for physical planning and urban development projects. This represents over $1,400 \%$ increment over what was earmarked for $2007-2009$ budgets. Further investigation revealed that over $60 \%$ of this budget had been released as at June 2010 (Table 5). This appears to be a major signal to the potential dividends derivable from the autonomy accorded physical planning in the State through the creation of a new Ministry.

\subsection{Development Control}

The Ministry does not possess enough human resources to effectively operate a physical planning mechanism. Monitoring officers are grossly inadequate (Table 1) while only few of the personnel are knowledgeable in the appropriate techniques of monitoring urban growth which include RS and GIS (Table 2). None of the 16 Area Offices is empowered sufficiently to be able to deliver development control services timely and effectively. It is pathetic to observe that the Ministry has only 3 vehicles to monitor urban development in the whole state. None of the Area offices has project vehicle. Enforcement of the existing regulations is rather weak. This is further aggravated by lack of an independent legal unit or department in the Ministry. Cases of contraventions are handled by the Ministry of Justice. The bureaucracy involved in this process is counter-productive to quick dispensation of justice on cases of contravention. Above all, interaction with developers indicates that town planning officials usually compromise the integrity of development control process through bribe taking.

\section{Towards Effective Planning in Ondo State}

For physical planning to be effective in Ondo State, it is imperative and urgent that autonomous Local Planning Authorities be established in the 18 LGAs of the State in consonance with the Nigerian Urban and Regional Planning Act 1992. For administrative convenience, it is further suggested that Zonal Offices should be established at 5 zonal centres of Okitipupa, Ondo, Owo, Ikare and Akure, to oversee the planning authorities. These centres are the former divisional headquarters in the State. Such autonomy would not only enhance service delivery, it would also become an impetus for revenue drive for these Authorities.

It should be realized that the structure suggested was not alien to the State as it was operated in the 70s. The structure collapsed mainly due to poor staffing. The Ministry must therefore commence without delay, the recruitment of young town planners that are well equipped technically to meet this challenge. Undoubtedly, every organization parades a certain level of capacity. It is desirable for such organization to build on this existing capacity. The Ministry must therefore encourage capacity building programmes that would foster training and re-training of her existing staff.

The importance of spatial or geo-information in the form of maps, plans, aerial photographs, satellite imageries cannot be over-emphasized. It is therefore urgent for the Ministry to commence the process of training all her staff in RS and GIS. In this regard, the Ministry can seek collaboration with the Regional Centre for Aerial Survey (RECTAS), Ile-Ife, Centre for Research in Space Studies (CESRA), The Federal University of Technology, Akure, the newly established Department of GIS/RS, The Federal University of Technology, Akure and National Space Research and Development Agency of Nigeria (NARSDA).

There is the need to expeditiously review the existing master plans. Development control cannot be effective when not built on an efficient and workable master plan. Settlements that are relatively large, especially, all LGAs headquarters must be identified for master planning purposes. This process must be accompanied by detailed preparation of comprehensive land use plans, subject plans, action area plans, district plans, local plans, and structure plans. From this set of communities, the state can gradually scale up to cover all other communities. Sufficient fund must be appropriated for this purpose in the State Budget. Money spent on such 'intangible' must not be considered as a waste rather a means of building liveable and sustainable communities whose implications on productivity, health and welfare are obvious.

Effective machinery should be set in motion for development control particularly in all urban areas. Appropriate techniques of monitoring urban growth, especially RS and GIS techniques must be adopted. Development control unit must be empowered sufficiently to be able to deliver its services timely and effectively. These include the provision of project vehicles and other logistics. For effective enforcement of the various laws, regulations and standards on physical planning, there is a need for the establishment of a well staffed legal department.

Again, rapid urban spread leading to unguided peri-urban development must be curtailed. Urban development must be restricted to its boundary in the master plan. Development including the erection of billboards along road abutments must be controlled. Strict and instantaneous penalties must be visited on those who violate rules and guidelines for development. Above all, the integrity of the development control process must be protected by the staff of this unit.

The ecological zones of the State vary and extensive. It ranges from the swamps around Ilaje/ Ese-Odo area to Guinea Savanna area in such areas like Akoko North East and Akoko North West. These have implications on physical planning. It is therefore critical to identify the different ecological zones in the State. The integration of the peculiarities of each zone with physical planning becomes an asset in the process of evolving sustainable communities in the state. 
One of the major issues of this century is the global increase in disaster events. Prominent among these are flooding and storms. Most communities in Ondo State are also prone to these forms of disaster. To forestall their occurrences, there is the need to identify all ecologically sensitive areas such as wetlands, river courses, hillsides among others in the state. The Ministry must evolve legislation that would control their usage. Such areas should be mapped out, well delineated and put under steady surveillance. The rate at which urban dwellers are building up hillsides in the State especially in Akure, the state capital is alarming. In like manner, the marginal land along major river valley in this city is constantly under siege by urban developers.

Urban aesthetics contribute to livability of the environment. Beautification of all urban areas should be accorded utmost priority by the new Ministry. This can be done through landscaping. It is a paradox that most open spaces that were delineated in master plans or family layouts in big cities such as Akure, Ondo and Owo had been over-run by urban growth. Conscious efforts must be made to create new open spaces and recreation areas in these communities. Attention must also be paid to tree planting as they enhance local climate and reduce the devastating effect of storms. It is further canvassed that all evolving master plans in the State must advocate environmental friendly and sustainable balanced city.

Development is about collaboration. Perhaps, the need for such partnership is more exemplified in physical planning as it requires inputs from all sectors in a bid to ensure efficiency and effectiveness. The new Ministry must therefore collaborate with both the Federal and State Ministries and Parastatals. Such partnership must be extended to the Local Governments and communities. The Ministry must realize that development is for the people and if so, it must be people-oriented. The people must be fully carried along and participate in the process. In this regard, the Ministry will be planning with the people and not for the people.

In addition, it is also important for the Ministry to put in place an effective public awareness mechanism that would ensure community penetrative sensitization/campaign on the need for an aesthetically pleasing, workable and livable communities in the State. Such mechanism would on a continuous basis educate communities on all emerging issues on physical development including the various regulations on development control. In addition, the mechanism shall promote the concepts of tree planting, environmental sanitation among others in these communities.

One area of deficiency in the 1992 National Urban and Regional Planning Law was its failure to specify areas of funding and fund generation for Planning Agencies. It becomes therefore imperative for Government to give priority to physical planning in budgetary allocation and disbursement of funds. This would enhance recruitment and retention of qualified staff, purchase of up-to-date equipments and provision of logistics. However, within the ambit of law, the new Ministry could look beyond State's allocation for financial resources by seeking avenues for generating income internally.

\section{Conclusion}

The establishment of a new Ministry of Physical Planning and Urban Development signals the seriousness that the government of Ondo State attaches to physical planning. It is a bold attempt at ensuring a result-oriented physical planning procedure in the State. The decision heralded the beginning of a revolution towards planning decentralization in the State. The Ministry must now use the opportunity of the respite offered to roll up its sleeves in order to put together a blueprint for a comprehensive overhaul of physical planning in Ondo State. To enable the Ministry optimize the potentials of physical planning in the State, the need to evolve an Urban Development Policy is imperative. Series of legislation and regulations must be enacted to ensure efficient and effective development control. At this stage of its development, the Ministry requires huge and timely financial support from the State Government in a bid to meeting the financial requirements of acquisition of equipment, hiring of new staff, capacity building in appropriate disciplines, preparation of master plans, acquisition of office space and other logistics. Spatial information and data in the forms of maps, including topographic maps at appropriate scales, remote sensing from satellite, geographic information systems (GIS) and other related communication technology among others are essential tools for sustainable physical planning. The Ministry with the support of the State Government must invest heavily in these indispensable instruments.

The Development Control Department has to be strengthened to meet the complexity of the present day urban system. Logistic supports especially project vehicles are essential for this Department. It is also desirable for the Ministry to evolve a participatory approach in her physical development efforts. This is the only means of ensuring the workability and sustainability of any development plan that would be prepared by the Ministry. As part of ensuring public participation, it is further suggested that all legislation and regulations including building codes guiding physical planning should be prepared in English and local dialects. These should be made available to all stakeholders. Finally, the staff of the newly created Ministry must ensure the integrity of physical planning process in the State by not compromising standards.

\section{References}

Alabi M.O. (2010). Prioritizing Factors of Failure in Controlling Physical Development in Nigerian Cities, Journal of Sustainable Development in Africa, 12 (2): 215-231. 
Alabi, M.O. and Akinbode, A. (2010). Toward Effective Physical Planning in Local Governments in Nigeria, Environmental Research Journal, 4(2): 173-176.

Aribigbola, A. (2007). Urban Land Use Planning Policies and Management in Sub Saharan Africa Countries, Empirical Evidences From Akure, Nigeria, Forth Urban Research Symposium, 2007.

Aribigbola, A. (2008). Improving Urban Land Use Planning and Management in Nigeria: The Case of Akure. Theoretical and Empirical Researches in Urban Management, 3 (9): 1-14.

Oduwaye, L. (2009). Challenges of Sustainable Physical Planning and Development in Metropolitan Lagos, Journal of Sustainable Development 2(1): 159-171.

Okpala D.C.I. (2001). Spatial Information: The Basic Tool for Sustainable Human Settlements Development Planning and Management, International Conference on Spatial Information for Sustainable Development, Nairobi, Kenya, 2-5 October 2001.

Onibokun. (1985). Physical Planning within the Framework of National Development Planning in Nigeria, Habitat International, 9(3-4): 157-177.

Table 1. Staff Structure

\begin{tabular}{llllll}
\hline S/N & Cadre & $\begin{array}{l}\text { No. } \\
\text { Expected }\end{array}$ & $\begin{array}{l}\text { No. in } \\
\text { place }\end{array}$ & $\begin{array}{l}\text { No. in place as a \% } \\
\text { of No. expected }\end{array}$ & Capacity Gap \\
\hline 1 & Professional staff & 64 & 20 & 31.3 & 68.7 \\
2 & Technical staff & 145 & 48 & 33.1 & 66.9 \\
3 & Administrative Staff & 47 & 36 & 76.6 & 23.4 \\
& Total & $\mathbf{2 4 8}$ & $\mathbf{1 0 4}$ & $\mathbf{5 8 . 1}$ & $\mathbf{4 1 . 9}$ \\
\hline
\end{tabular}

Source: Field Survey, 2010

Table 2. Staff with Special Skills

\begin{tabular}{lll}
\hline S/N & Type of Skill & No. of Staff \\
\hline 1 & Geographical Information Systems (GIS) and Remote Sensing (RS) & 1 \\
2 & Risk and Disaster Management & 0 \\
3 & Coastal Zone Management and Planning & 0 \\
& Total & $\mathbf{1}$
\end{tabular}

Source: Field Survey, 2010

Table 3. Training in the past 5 Years

\begin{tabular}{llll}
\hline S/N & Type of Training & Year Trained & No. Trained \\
\hline 1 & Geographical Information Systems (GIS) & 2008 & 1 \\
2 & AutoCad & 2007 & 16 \\
3 & Computer Appreciation & 2006 & 18 \\
& Total & & $\mathbf{3 5}$ \\
\hline
\end{tabular}

Source: Field Survey, 2010

Table 4. Master Planning in Ondo State

\begin{tabular}{llll}
\hline S/N & Settlement & Year Designed & Year Reviewed \\
\hline 1 & Akure & 1979 & 2000 \\
2 & Ondo & 1980 & 2001 \\
3 & Ore & 1998 & 2009 \\
4 & Owo & 1988 & Not yet reviewed \\
5 & Ikare & 1988 & Not yet reviewed \\
\hline
\end{tabular}

Source: Field Survey, 2010 
Table 5. Capital Budget on Physical Planning and Urban Development between 2007 and 2010

\begin{tabular}{llll}
\hline Year & Estimate (USD in millions) & Actual (USD in millions) & \% Draw-down \\
\hline 2007 & 0.020 & 0.012 & 60.0 \\
2008 & 0.020 & 0.01 & 50.0 \\
2009 & 0.022 & 0.013 & 59.1 \\
$* 2010$ & 8.72 & & \\
Total & $\mathbf{8 . 8 2 2}$ & & \\
\hline
\end{tabular}

Source: Field Survey, 2010

* As at June, 2010 over $60 \%$ of the Budget Estimate has been released

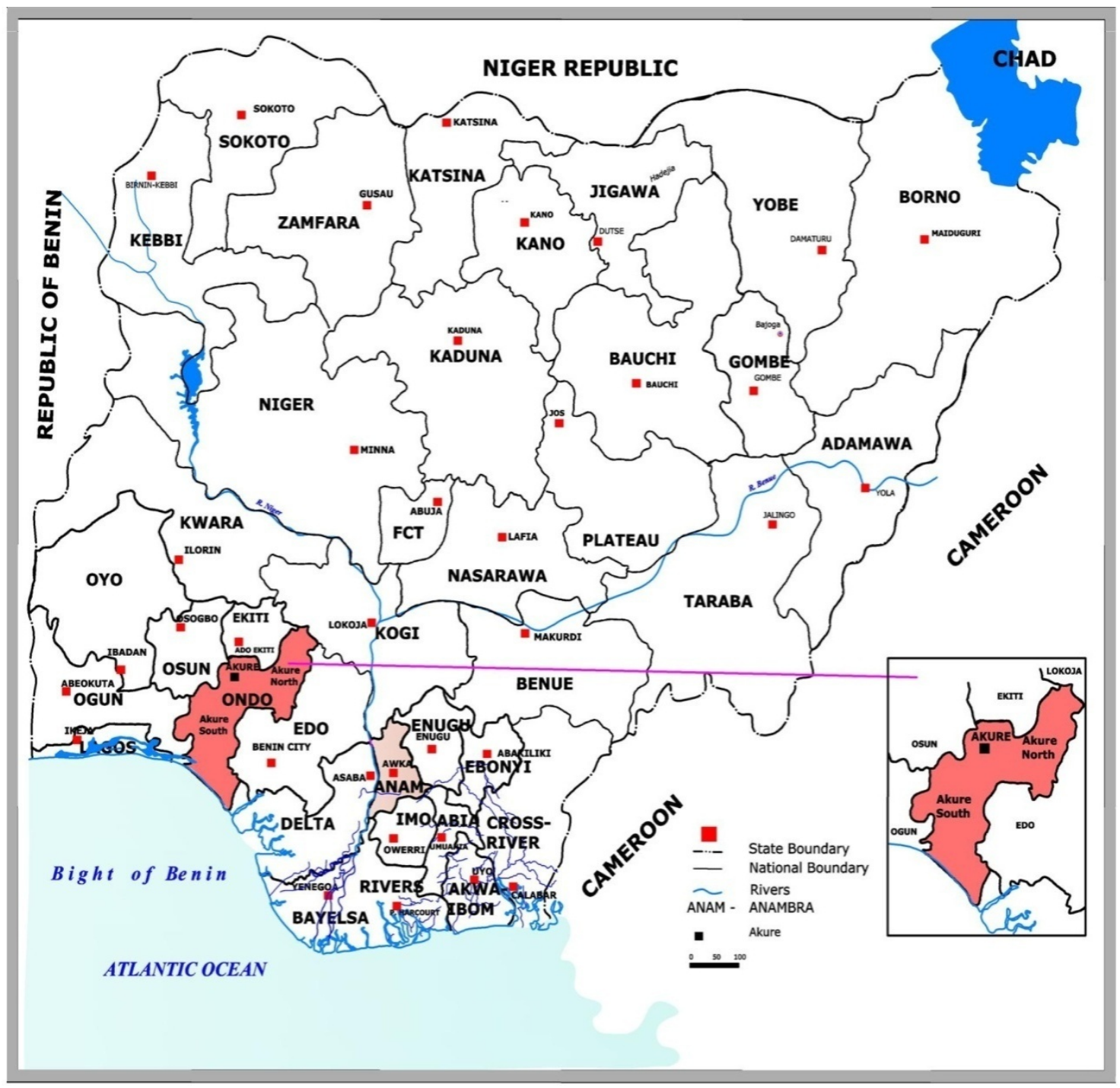

Figure 1. Ondo State in Nigeria 